Synthesis and Characterization of Phthalimide-benzothiazole

Mercury(II) Complexes with Diphosphine and Diamines

Ahmed Abdul sattar Irzoqi , Ahmed Shaker Marmmus Al-Janabi , Hayfa Muhammed Jirjes

\title{
Synthesis and Characterization of Phthalimide-benzothiazole Mercury(II) Complexes with Diphosphine and Diamines
}

\author{
Ahmed Abdul sattar Irzoqi ${ }^{1}$ Ahmed Shaker Marmmus Al-Janabi ${ }^{2}$ \\ Hayfa Muhammed Jirjes ${ }^{3}$ \\ ${ }^{1}$ Dep. of chemistry- College of Education for Pure Science- University of Tikrit. \\ ${ }^{2}$ Dep. of Biochemistry- College of Veterinary Medicine-University of Tikrit. \\ ${ }^{3}$ Dep. of chemistry- College of Science-University of Tikrit.
}

Received 25 March 2016 ; Accepted 18 May 2016

\begin{abstract}
$\underline{\text { Abstract }}$
Phthalimide-benzothiazole ligand (L) and their complexes of $\mathrm{Hg}(\mathrm{II})$ with diphosphine and diamines have been prepared. Conductivity measurements show the 2:1 (ion- complex ion) behavior of the complexes except for $\left[\mathrm{Hg}(\mathrm{L}) \mathrm{Cl}_{2}\right](1)$ complex which was non-conductive. The Phthalimide-benzothiazole ligand has been observed to be bonded to the $\mathrm{Hg}$ (II) ion through the nitrogen and oxygen atoms as a bidentate chelating ligand, whereas the diphosphine and diamine ligands have been bonded as bidentate chelating ligands to give a tetrahedral geometry around the $\mathrm{Hg}(\mathrm{II})$ ion.
\end{abstract}

Keywords: Phthalimide, Mercury, phosphine, complexes 
Synthesis and Characterization of Phthalimide-benzothiazole

Mercury(II) Complexes with Diphosphine and Diamines

Ahmed Abdul sattar Irzoqi , Ahmed Shaker Marmmus Al-Janabi , Hayfa Muhammed Jirjes

تحضير وتثخيص معقدات فثالامايد_بنزوثايازول الزئبق (II) مع ليكاندات الفوسفينات والامينات

الثنائية

احمد عبدالستار ارزوقي1 احمد شاكر مرموص الجنابي2 هيفاء محمد جرجيس3

1 جامعة تكريت ـ كلية التربية للعلوم الصرفة ـ ـ قامم الكيمياء

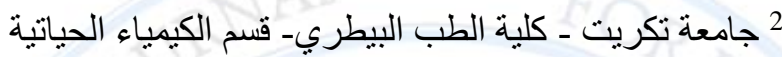

3

\section{الخلاصة}

تم تحضير ليكاند فثالامايد-بنزوثايازول (L) مع عدد من معقدات الزئبق (II) و الفوسفينات والامينات الثنائية. ووجد من خلال

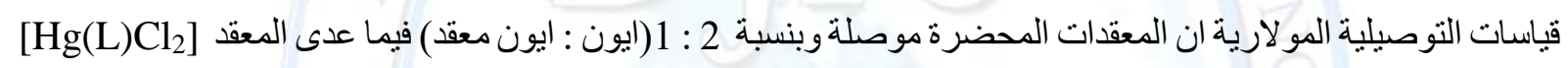
(1) الذي يكون غير موصل. وجد في المعقدات المحضرة ان ليكاند فثالامايد-بنزونثايازول يسلك سلوك ليكاند ثنائي السن المخلبي يرتبط من خلال ذرتي النتروجين و الاوكسجين، في حين ترتبط ليكاندات الفوسفينات و الامينات الثنائية بشكل ثنائي السن المخلبي ايضاً لتعطي ترتيب رباعي السطوح حول ايون الزئبق (II). كلمات مفتاحية: فتالامايد، الزئبق ، الفوسفين، المعقدات.

\section{Introduction}

The phthalimide compounds possess a structural features - $\mathrm{CO}-\mathrm{N}(\mathrm{R})-\mathrm{CO}$ - and a heterocyclic ring help the phthalimide to be pharmaceutically useful and biologically active[1]. Phthalimides and benzothiazoles have received attention due to their antitumour [2,3], anxiolytic [4] antifungal, antibacterial, analgesic [5], and anti HIV-1 activities. Several metal complexes of Mannich bases are known to have antimalarial, anti-inflammatory and antimicrobial drugs [613]. Recently, we reported several new mixed ligand complexes of $\mathrm{Hg}$ (II) with Phthalimidebenzothiazole as primary ligand and diphosphine and diamines as co-ligands. 
Synthesis and Characterization of Phthalimide-benzothiazole

Mercury(II) Complexes with Diphosphine and Diamines

Ahmed Abdul sattar Irzoqi , Ahmed Shaker Marmmus Al-Janabi , Hayfa Muhammed Jirjes

\section{$\underline{\text { Experimental }}$}

\section{General and instrumental}

All the reagents, starting materials as well as solvents were purchased commercially and used without any further purification. The melting points were recorded on SMP40 supplied by Stuart Company. Elemental C, H, and N analysis were carried out on Eurovectro, EA 3000A, Italy. Infrared spectra (with $\mathrm{KBr}$ disc) were recorded in the $4000-400 \mathrm{~cm}^{-1}$ range on Shimadzu 8400S FTIR Spectrophotometer. Conductivity measurements were carried out using a WTW conductivity meter. The ${ }^{1} \mathrm{H}-\mathrm{NMR}$ spectra were recorded on Bruker, Ultra Shield $300 \mathrm{MHz}$, Switzerland spectrometer using DMSO-d6 as a solvent and TMS as an internal reference.

\section{Synthesis of Phthalimide-benzothiazoles (L)}

A suspension of phthalic anhydride $(1.481 \mathrm{~g}, 0.010 \mathrm{mmole})$ in glacial acetic acid $(10 \mathrm{ml})$ was added to a suspension of 2-aminobenzothiazole (1.502 g, $0.010 \mathrm{mmol})$ in glacial acetic acid (10 $\mathrm{ml})$. The mixture was refluxed for 3 hours. The clear solution formed was left for solvent to evaporate at room temperature to give white crystals. The crystals were collected by filtration and dried under vacuum. This compound had been prepared by a rather different method [14]. (L): white crystals $\left(2.00 \mathrm{~g}, 71 \%\right.$ ). Anal. Calc. for $\mathrm{C}_{15} \mathrm{H}_{8} \mathrm{~N}_{2} \mathrm{O}_{2} \mathrm{~S}$ : C, 64.27; H, 2.88; N, 9.99. Found: C, 64.22; H, 2.92; N, 10.03\%. IR (KBr):3091w(CH aromatic), 1785m,1730s $(\mathrm{C}=\mathrm{O})$, $1591 \mathrm{~s}(\mathrm{C}=\mathrm{N}), 1456 \mathrm{~m}(\mathrm{C}=\mathrm{C}), 748 \mathrm{~m}(\mathrm{C}-\mathrm{S}-\mathrm{C}) \mathrm{cm}^{-1}$. ${ }^{1} \mathrm{H}$ NMR $\left(\mathrm{DMSO}-\mathrm{d}^{6}\right): \delta 7.33(\mathrm{td}, 1 \mathrm{H}){ }^{3} \mathrm{~J}(\mathrm{HH})=$ $7.32 \mathrm{~Hz}, \quad{ }^{4} \mathrm{~J}(\mathrm{HH})=\quad 1.24 \mathrm{~Hz} ; \quad 7.41(\mathrm{td}, 1 \mathrm{H}) \quad{ }^{3} \mathrm{~J}(\mathrm{HH})=\quad 7.22 \mathrm{~Hz}, \quad{ }^{4} \mathrm{~J}(\mathrm{HH})=\quad 1.35 \mathrm{~Hz} ; 7.82-$ 7.84(m,2H);7.89(d,1H);7.91-7.93(m,2H);8.01(d,1H) ppm. Melting point: $258^{\circ} \mathrm{C}$ decomposes.

\section{Synthesis of $\left[\mathrm{Hg}(\mathrm{L}) \mathrm{Cl}_{2}\right](1)$}

A suspension of $\mathrm{HgCl}_{2}(0.271 \mathrm{~g}, 1.000 \mathrm{mmole})$ in $\mathrm{CHCl}_{3}(10 \mathrm{ml})$ was added to a solution of Phthalimide - benzothiazole (L) $(0.280 \mathrm{~g}, 1.000 \mathrm{mmole})$ in $\mathrm{CHCl}_{3}(10 \mathrm{ml})$. The final mixture was refluxed for two hours, the white precipitate was formed, which was filtered off, dried under vacuum. 
Synthesis and Characterization of Phthalimide-benzothiazole

Mercury(II) Complexes with Diphosphine and Diamines

\section{Ahmed Abdul sattar Irzoqi , Ahmed Shaker Marmmus Al-Janabi , Hayfa Muhammed Jirjes}

\section{Synthesis of $[\mathrm{Hg}(\mathrm{L})(\mathrm{Bipy})] \mathrm{Cl}_{2}(2)$}

A suspension of $\mathrm{HgCl}_{2}(0.271 \mathrm{~g}, 1.000 \mathrm{mmole})$ in $\mathrm{CHCl}_{3}(10 \mathrm{ml})$ was added to a solution of Phthalimide-benzothiazole (L) $(0.280 \mathrm{~g}, 1.000 \mathrm{mmole})$ in $\mathrm{CHCl}_{3}(10 \mathrm{ml})$. The mixture was refluxed for three hours. The white suspension formed was added to a solution of Bipy $(0.172$ g, 1.000 mmole $)$ in $\mathrm{CHCl}_{3}(10 \mathrm{ml})$. The final mixture was refluxed for three hours; the yellow solution was formed, which was filtered off, then left for solvent to evaporate at room temperature to give pale yellow solid which filtered off, dried under vacuum.

The related complexes $[\mathrm{Hg}(\mathrm{L})(\mathrm{Phen})] \mathrm{Cl}_{2}(\mathbf{3}),[\mathrm{Hg}(\mathrm{L})(\mathrm{dppe})] \mathrm{Cl}_{2}(\mathbf{4}),[\mathrm{Hg}(\mathrm{L})(\mathrm{dppp})] \mathrm{Cl}_{2}$ (5) and $[\mathrm{Hg}(\mathrm{L})(\mathrm{dppb})] \mathrm{Cl}_{2}(\mathbf{6})$ were prepared and isolated by similar method.

(1) White precipitate, $(0.472 \mathrm{~g}, 85 \%)$. Anal. Calc. for $\mathrm{C}_{15} \mathrm{H}_{8} \mathrm{Cl}_{2} \mathrm{HgN}_{2} \mathrm{O}_{2} \mathrm{~S}: \mathrm{C}, 32.65 ; \mathrm{H}, 1.46$; $\mathrm{N}$, 5.08. Found: C, 32.92; H, 1.64; N, $5.44 \%$. IR (KBr): 3052w(CH aromatic), $1722 \mathrm{~m}$, $1652 \mathrm{~s}(\mathrm{C}=\mathrm{O}), 1542 \mathrm{~m}(\mathrm{C}=\mathrm{N}), 1468 \mathrm{~m}(\mathrm{C}=\mathrm{C}), 748 \mathrm{~m}(\mathrm{C}-\mathrm{S}-\mathrm{C}) \mathrm{cm}^{-1} \cdot{ }^{1} \mathrm{H}$ NMR $\left(\mathrm{DMSO}-\mathrm{d}^{6}\right): \delta$ 7.33(t,2H) ${ }^{3} \mathrm{~J}(\mathrm{HH})=7.41 \mathrm{~Hz} ; 7.42(\mathrm{t}, 2 \mathrm{H})^{3} \mathrm{~J}(\mathrm{HH})=7.51 \mathrm{~Hz} ; 7.80-7.94(\mathrm{~m}, 4 \mathrm{H})$ ppm. Melting point: $231^{\circ} \mathrm{C}$ decomposes.

(2) Pale yellow precipitate, (0.613 g, 86\%). Anal. Calc. for $\mathrm{C}_{25} \mathrm{H}_{16} \mathrm{Cl}_{2} \mathrm{HgN}_{4} \mathrm{O}_{2} \mathrm{~S}: \mathrm{C}, 42.41 ; \mathrm{H}$, 2.28; N, 7.91. Found: C, 42.12; H, 2.11; N, 7.53\%. IR (KBr):3068w(CH aromatic), 1755m, $1690 \mathrm{~s}(\mathrm{C}=\mathrm{O}), \quad 1563 \mathrm{~s} \quad(\mathrm{C}=\mathrm{N}), 1454 \mathrm{~m} \quad(\mathrm{C}=\mathrm{C}), 746 \mathrm{~m}(\mathrm{C}-\mathrm{S}-\mathrm{C}) \quad \mathrm{cm}^{-1} \cdot{ }^{1} \mathrm{H}$ NMR $\left(\mathrm{DMSO}^{6} \mathrm{~d}^{6}\right): \delta$ $6.93(\mathrm{td}, 2 \mathrm{H}){ }^{3} \mathrm{~J}(\mathrm{HH})=5.10 \mathrm{~Hz},{ }^{4} \mathrm{~J}(\mathrm{HH})=1.09 \mathrm{~Hz} ; 6.85(\mathrm{td}, 1 \mathrm{H}){ }^{3} \mathrm{~J}(\mathrm{HH})=7.40 \mathrm{~Hz},{ }^{4} \mathrm{~J}(\mathrm{HH})=1.56 \mathrm{~Hz} ;$ $7.17(\mathrm{td}, 1 \mathrm{H}){ }^{3} \mathrm{~J}(\mathrm{HH})=7.50 \mathrm{~Hz},{ }^{4} \mathrm{~J}(\mathrm{HH})=1.56 \mathrm{~Hz} ; 7.48(\mathrm{td}, 2 \mathrm{H}){ }^{3} \mathrm{~J}(\mathrm{HH})=7.87 \mathrm{~Hz},{ }^{4} \mathrm{~J}(\mathrm{HH})=1.27 \mathrm{~Hz}$; 7.81-7.83(m,2H); 7.88(dd,1H); 7.92(dd,1H); 7.97-7.99(m,2H); $8.52(\mathrm{dd}, 2 \mathrm{H}){ }^{3} \mathrm{~J}(\mathrm{HH})=4.99 \mathrm{~Hz}$; $8.81(\mathrm{~d}, 2 \mathrm{H})^{3} \mathrm{~J}(\mathrm{HH})=8.03 \mathrm{~Hz}$ ppm. Melting point: $289^{\circ} \mathrm{C}$ decomposes.

(3) Yellow precipitate, (0.604 g, 82\%). Anal. Calc. for $\mathrm{C}_{27} \mathrm{H}_{16} \mathrm{Cl}_{2} \mathrm{HgN}_{4} \mathrm{O}_{2} \mathrm{~S}$ : C, 44.30; $\mathrm{H}, 2.20$; $\mathrm{N}$, 7.65. Found: C, 44.21; H, 2.56; N, $7.51 \%$. IR (KBr): 3068w(CH aromatic), $1753 \mathrm{~m}$, $1695 \mathrm{~s}(\mathrm{C}=\mathrm{O}), 1566 \mathrm{~m}(\mathrm{C}=\mathrm{N}), 1456 \mathrm{~m}(\mathrm{C}=\mathrm{C}), 747 \mathrm{~m}(\mathrm{C}-\mathrm{S}-\mathrm{C}) \mathrm{cm}^{-1} \cdot{ }^{1} \mathrm{H}$ NMR $\left(\mathrm{DMSO}-\mathrm{d}^{6}\right): \delta$ $6.99(\mathrm{td}, 1 \mathrm{H}){ }^{3} \mathrm{~J}(\mathrm{HH})=7.41 \mathrm{~Hz},{ }^{4} \mathrm{~J}(\mathrm{HH})=1.57 \mathrm{~Hz} ; 7.19(\mathrm{td}, 1 \mathrm{H}){ }^{3} \mathrm{~J}(\mathrm{HH})=7.48 \mathrm{~Hz},{ }^{4} \mathrm{~J}(\mathrm{HH})=1.47 \mathrm{~Hz}$; $7.68(\mathrm{t}, 2 \mathrm{H}){ }^{3} \mathrm{~J}(\mathrm{HH})=7.46 \mathrm{~Hz} ; 7.81-7.83(\mathrm{~m}, 2 \mathrm{H}) ; 7.87(\mathrm{dd}, 1 \mathrm{H}) ; 7.91(\mathrm{dd}, 1 \mathrm{H}) ; 7.97-7.99(\mathrm{~m}, 2 \mathrm{H})$; $8.01(\mathrm{~s}, 2 \mathrm{H}) ; 8.51(\mathrm{~d}, 2 \mathrm{H}){ }^{3} \mathrm{~J}(\mathrm{HH})=7.47 \mathrm{~Hz} ; 9.13(\mathrm{dd}, 2 \mathrm{H}) \mathrm{ppm}^{3} \mathrm{~J}(\mathrm{HH})=7.50 \mathrm{~Hz},{ }^{4} \mathrm{~J}(\mathrm{HH})=1.45 \mathrm{~Hz}$. Melting point: $273^{\circ} \mathrm{C}$ decomposes. 
Synthesis and Characterization of Phthalimide-benzothiazole

Mercury(II) Complexes with Diphosphine and Diamines

Ahmed Abdul sattar Irzoqi , Ahmed Shaker Marmmus Al-Janabi , Hayfa Muhammed Jirjes

(4) Pale orange precipitate, $(0.768 \mathrm{~g}, 80 \%)$. Anal. Calc. for $\mathrm{C}_{41} \mathrm{H}_{32} \mathrm{Cl}_{2} \mathrm{HgN}_{2} \mathrm{O}_{2} \mathrm{P}_{2} \mathrm{~S}$ : C, 51.82; H, 3.39; N, 2.95. Found: C, 51.73; H, 3.43; N, $2.84 \%$. IR (KBr): 3055w(CH aromatic), 1750m, $1682 \mathrm{~s}(\mathrm{C}=\mathrm{O}), 1567 \mathrm{~m}(\mathrm{C}=\mathrm{N}), 1455 \mathrm{~m}(\mathrm{C}=\mathrm{C}), 1434 \mathrm{~s}, 690 \mathrm{~s}(\mathrm{C}-\mathrm{P}), 748 \mathrm{~m}(\mathrm{C}-\mathrm{S}-\mathrm{C}) \mathrm{cm}^{-1}$. ${ }^{1} \mathrm{H}$ NMR $\left(\mathrm{DMSO}^{6} \mathrm{~d}^{6}\right): \delta 1.40\left({ }^{*} \mathrm{vq}, 4 \mathrm{H}\right) ; 6.99(\mathrm{t}, 1 \mathrm{H}){ }^{3} \mathrm{~J}(\mathrm{HH})=7.41 \mathrm{~Hz} ; 7.19(\mathrm{t}, 1 \mathrm{H}){ }^{3} \mathrm{~J}(\mathrm{HH})=7.50 \mathrm{~Hz} ; 7.27-$ 7.38(m,20H); 7.80-7.84(m,2H); 7.88(d,1H); 7.91(d,1H); 7.96-7.99(m,2H) ppm. Melting point: $196^{\circ} \mathrm{C}$ decomposes.

*vq: virtual quartet

(5) Pale orange precipitate, $(0.758 \mathrm{~g}, 78 \%)$. Anal. Calc. for $\mathrm{C}_{42} \mathrm{H}_{34} \mathrm{Cl}_{2} \mathrm{HgN}_{2} \mathrm{O}_{2} \mathrm{P}_{2} \mathrm{~S}$ : C, 52.32; H, 3.55; N, 2.91. Found: C, 51.96; H, 3.41; N, $2.64 \%$. IR (KBr): 3054w(CH aromatic), 1751m, $1681 \mathrm{~s}(\mathrm{C}=\mathrm{O}), 1567 \mathrm{~m}(\mathrm{C}=\mathrm{N}), 1454 \mathrm{~m}(\mathrm{C}=\mathrm{C}), 1433 \mathrm{~m}, 694 \mathrm{~s}(\mathrm{C}-\mathrm{P}), 747 \mathrm{~m}(\mathrm{C}-\mathrm{S}-\mathrm{C}) \mathrm{cm}^{-1} .{ }^{1} \mathrm{H}$ NMR $\left(\mathrm{DMSO}^{6} \mathrm{~d}^{6}\right): \delta 1.28-1.33(\mathrm{~m}, 4 \mathrm{H}) ; 1.37-1.45(\mathrm{~m}, 2 \mathrm{H}) ; 6.99(\mathrm{t}, 1 \mathrm{H}){ }^{3} \mathrm{~J}(\mathrm{HH})=7.40 \mathrm{~Hz} ; 7.19(\mathrm{t}, 1 \mathrm{H})$ ${ }^{3} \mathrm{~J}(\mathrm{HH})=7.51 \mathrm{~Hz} ; \quad 7.28-7.38(\mathrm{~m}, 20 \mathrm{H}) ; \quad 7.81-7.83(\mathrm{~m}, 2 \mathrm{H}) ; \quad 7.88(\mathrm{~d}, 1 \mathrm{H}) ; \quad 7.92(\mathrm{~d}, 1 \mathrm{H}) ; \quad 7.97-$ 7.99(m,2H); ppm. Melting point: $224^{\circ} \mathrm{C}$ decomposes.

(6) pale orange precipitate, $\left(0.758 \mathrm{~g}, 77 \%\right.$ ). Anal. Calc. for $\mathrm{C}_{43} \mathrm{H}_{36} \mathrm{Cl}_{2} \mathrm{HgN}_{2} \mathrm{O}_{2} \mathrm{P}_{2} \mathrm{~S}$ : C, 52.79; $\mathrm{H}$, 3.71; N, 2.86. Found: C, 52.96; H, 3.63; N, $3.04 \%$. IR (KBr): 3052w(CH aromatic), 1753m, $1680 \mathrm{~s}(\mathrm{C}=\mathrm{O}), 1566 \mathrm{~m}(\mathrm{C}=\mathrm{N}), 1465 \mathrm{~m}(\mathrm{C}=\mathrm{C}), 1434 \mathrm{~m}, 693 \mathrm{~s}(\mathrm{C}-\mathrm{P}), 748 \mathrm{~m}(\mathrm{C}-\mathrm{S}-\mathrm{C}) \mathrm{cm}^{-1} .{ }^{1} \mathrm{H}$ NMR $\left.\left(\mathrm{DMSO}^{6}\right)^{6}\right): \delta 1.26-1.33(\mathrm{~m}, 4 \mathrm{H}) ; 1.36-1.39(\mathrm{~m}, 4 \mathrm{H}) ; 6.98(\mathrm{t}, 1 \mathrm{H}){ }^{3} \mathrm{~J}(\mathrm{HH})=7.41 \mathrm{~Hz} ; 7.19(\mathrm{t}, 1 \mathrm{H})$ ${ }^{3} \mathrm{~J}(\mathrm{HH})=7.51 \mathrm{~Hz} ; \quad 7.28-7.39(\mathrm{~m}, 20 \mathrm{H}) ; \quad 7.80-7.84(\mathrm{~m}, 2 \mathrm{H}) ; \quad 7.88(\mathrm{~d}, 1 \mathrm{H}) ; \quad 7.92(\mathrm{~d}, 1 \mathrm{H}) ; \quad 7.96-$ 7.99(m,2H) ppm. Melting point: $256^{\circ} \mathrm{C}$ decomposes.

\section{$\underline{\text { Results and Discussion }}$}

Preparation of the ligand and its new complexes are represented in Scheme 1 and 2.

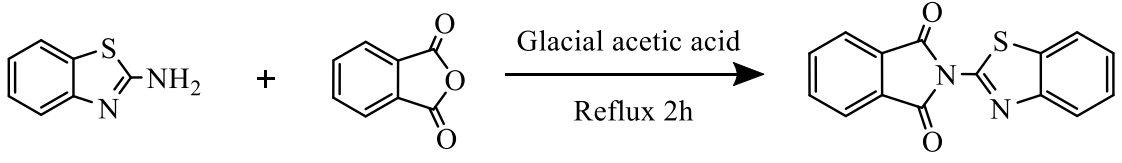

Scheme 1: Preparation of phthalimide-benzothiazole ligand (L) 
Synthesis and Characterization of Phthalimide-benzothiazole

Mercury(II) Complexes with Diphosphine and Diamines

Ahmed Abdul sattar Irzoqi , Ahmed Shaker Marmmus Al-Janabi , Hayfa Muhammed Jirjes

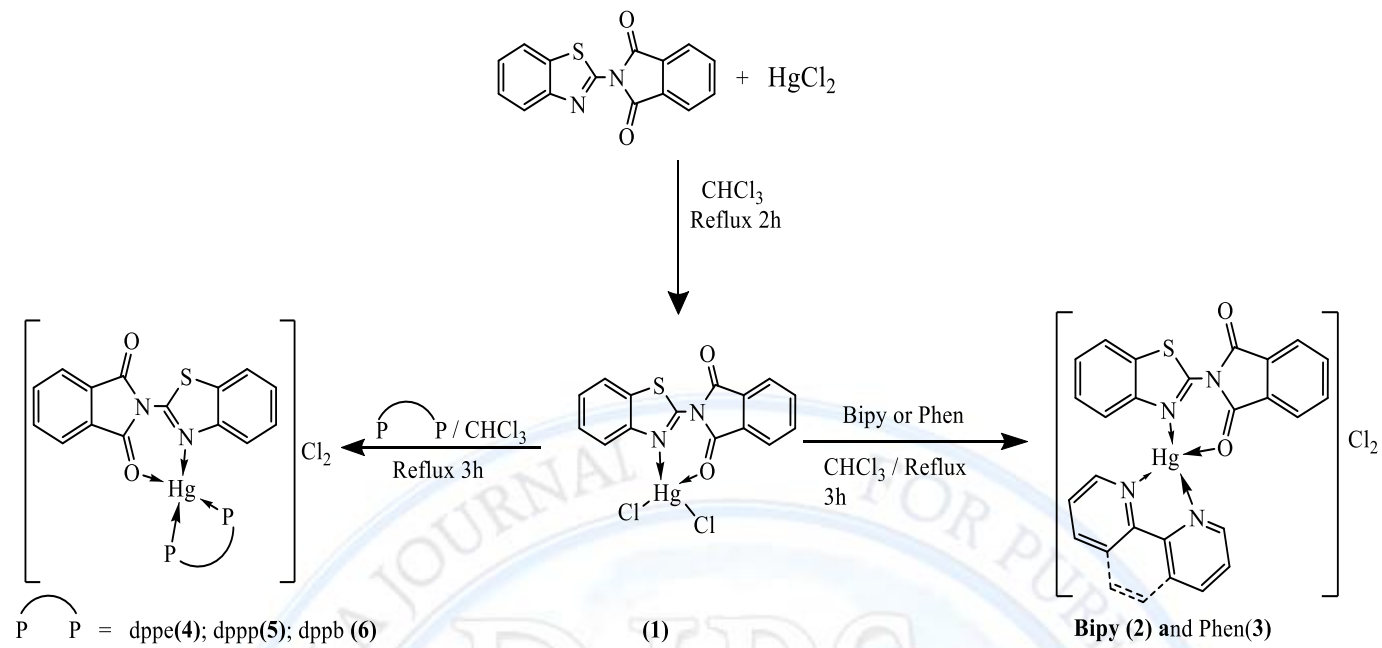

Scheme 2: Preparation of complexes (1-6)

The prepared complexes are air-stable, insoluble in $\mathrm{EtOH}, \mathrm{MeOH}$, acetone and water, but soluble in $\mathrm{CHCl}_{3}$, DMSO and DMF. Molar conductance values of $\mathrm{Hg}(\mathrm{II})$ complexes in DMSO solution correspond to 1:2 electrolytic nature [15], as shown in table (1).

Table (1) Shows Molar Conductivity of the Prepared Complexes at $1 \times 10^{-3}$ concentration in DMSO.

\begin{tabular}{|r|c|c|}
\hline No. & Complexes & \multicolumn{1}{|c|}{${ }^{\mathrm{m}}$} \\
& {$\left[\mathrm{Cm}^{2} . \mathrm{ohm}^{-1} \cdot \mathrm{mol}^{-1}\right)$} \\
\hline 2 & {$\left[\mathrm{Hg}(\mathrm{L}) \mathrm{Cl}_{2}\right]$} & 20 \\
\hline 3 & {$\left[\mathrm{Hg}(\mathrm{L})\left(\mathrm{Bipy}^{-1}\right)\right] \mathrm{Cl}_{2}$} & 73 \\
\hline 4 & {$\left[\mathrm{Hg}(\mathrm{L}(\mathrm{L})(\mathrm{dppe})] \mathrm{Cl}_{2}\right.$} & $\mathbf{7 1 . 5}$ \\
\hline 5 & {$[\mathrm{Hg}(\mathrm{L})(\mathrm{dppp})] \mathrm{Cl}_{2}$} & 78 \\
\hline 6 & {$[\mathrm{Hg}(\mathrm{L})(\mathrm{dppb})] \mathrm{Cl}_{2}$} & 76 \\
\hline
\end{tabular}

The coordination of the $\mathrm{Hg}(\mathrm{II})$ ion to the ligand (L) affected the $v(\mathrm{C}=\mathrm{O})$ asy/sy and $v(\mathrm{C}=\mathrm{N})$ stretching vibrations. The $v(\mathrm{C}=\mathrm{O})$ asy/sy and $v(\mathrm{C}=\mathrm{N})$ that show at $(1785 / 1730) \mathrm{cm}^{-1}$ 
Synthesis and Characterization of Phthalimide-benzothiazole

Mercury(II) Complexes with Diphosphine and Diamines

\section{Ahmed Abdul sattar Irzoqi , Ahmed Shaker Marmmus Al-Janabi , Hayfa Muhammed Jirjes}

and $(1591) \mathrm{cm}^{-1}$ in the free ligand, shifted to lower frequencies in all prepared complexes indicating that the $\mathrm{Hg}$ (II) ion is coordinated through to the oxygen / nitrogen atoms of the $\mathrm{L}$ ligand[6-9] a new bands were observed in the IR spectra of the $[\mathrm{HgL}(\operatorname{diphos})]$ (diphos $=$ dppe, dppp and dppb) which didn't found in the spectrum of the $\left[\mathrm{HgCl}_{2} \mathrm{~L}\right]$ are the $v(\mathrm{P}-\mathrm{Ph})$ and $v(\mathrm{P}-$ C), observed within the $1434,1433,1434 \mathrm{~cm}^{-1}$ and $690,694,694 \mathrm{~cm}^{-1}$, respectively [16-18]. It is thought [18] that this vibration arises from the deformation of the planarity of the phenyl ring bonded to the phosphorus atom.

The ${ }^{1} \mathrm{H}$ NMR spectra of phthalimide-benzothiazole ligand (L) and its $\mathrm{Hg}$ (II) complexes were recorded in DMSO-d6 and are given with the experimental data.

The ${ }^{1} \mathrm{H}-\mathrm{NMR}$ spectrum that of phthalimide-benzothiazole ligand (L) (Fig 1), display the (a) and (d) protons as a doublet at $\delta 8.01 \mathrm{ppm}, \delta 7.87 \mathrm{ppm}$. whereas the protons in position (e) and (f) showed as unresolved multiplets peaks within $\delta(7.91-7.93)$ and $\delta(7.82-7.84)$ ppm range respectively. Each of these signals represent two protons, as indicated the integration values under each signal. And triplet of doublets at $\delta 7.41$ and $\delta 7.33 \mathrm{ppm}$ for the protons in position (b) and (c) respectively.

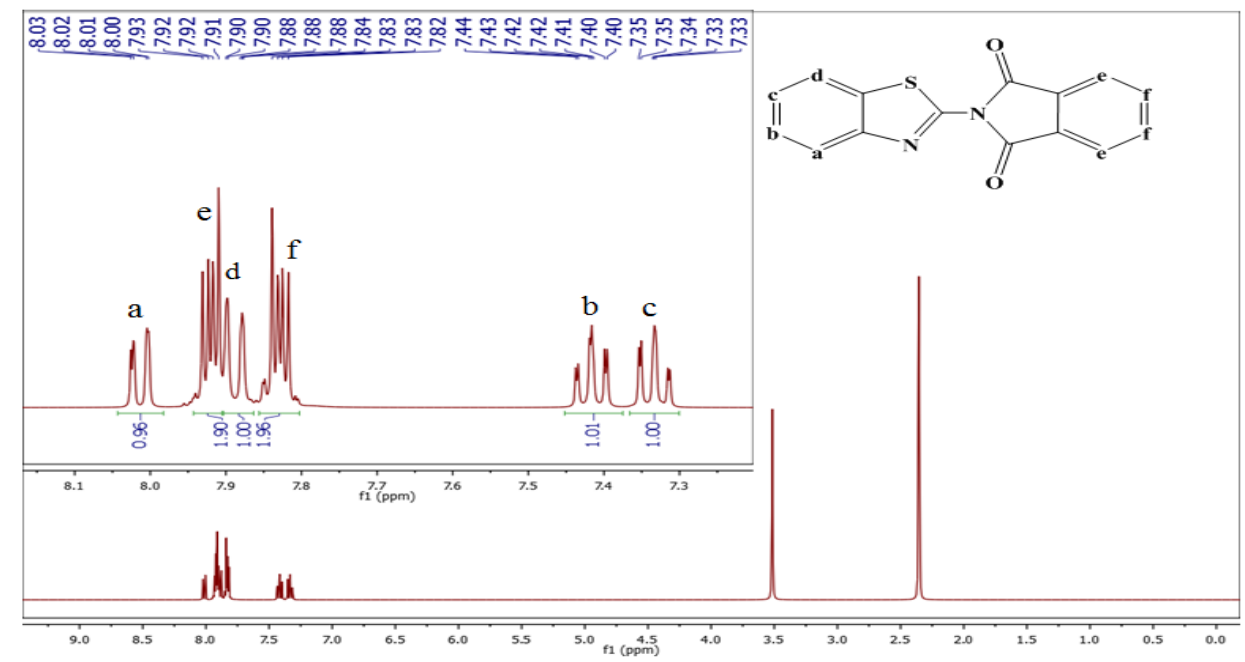

Fig 1: ${ }^{1} \mathrm{H}-\mathrm{NMR}$ Spectrum of Phthalimide-benzothiazole $(\mathrm{L})$ in DMSO-d ${ }^{6}$ 
Synthesis and Characterization of Phthalimide-benzothiazole

Mercury(II) Complexes with Diphosphine and Diamines

\section{Ahmed Abdul sattar Irzoqi , Ahmed Shaker Marmmus Al-Janabi , Hayfa Muhammed Jirjes}

The ${ }^{1} \mathrm{H}-\mathrm{NMR}$ spectrum of complex (1) shown three signals two as a triplet peak at $87.33 \mathrm{ppm}$, and $87.42 \mathrm{ppm}$ due to the protons in position (c) and (b) respectively. whereas the other peak showed as unresolved multiplets peaks within $\delta(7.80-7.98)$ ppm.

The ${ }^{1} \mathrm{H}-\mathrm{NMR}$ spectra of each displayed the expected signals for the phthalimide-benzothiazole ligand as well as diamines and phosphine ligands (see Figs. 2 to 4).

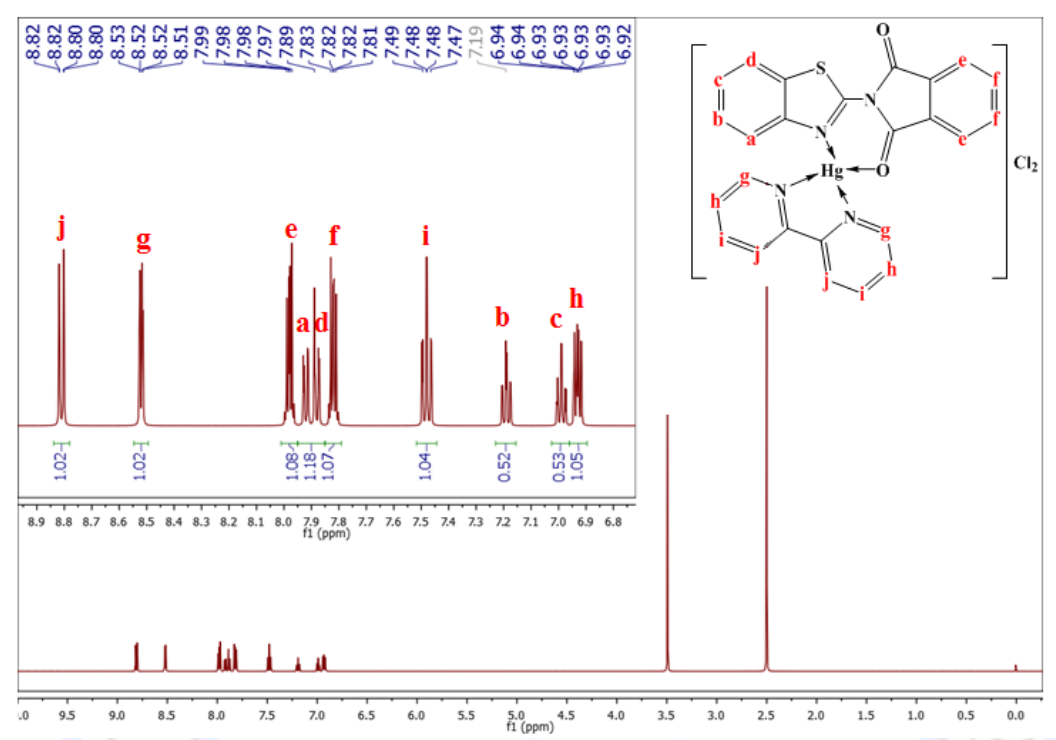

Fig 2. ${ }^{1} \mathrm{H}-\mathrm{NMR}$ Spectrum of $[\mathrm{Hg}(\mathrm{L})(\mathrm{Bipy})] \mathrm{Cl}_{2}$ in $\mathrm{DMSO}-\mathrm{d}^{6}$ 


\section{DIYALA JOURNAL FOR PURE SCIENCES}

Synthesis and Characterization of Phthalimide-benzothiazole

Mercury(II) Complexes with Diphosphine and Diamines

Ahmed Abdul sattar Irzoqi , Ahmed Shaker Marmmus Al-Janabi , Hayfa Muhammed Jirjes

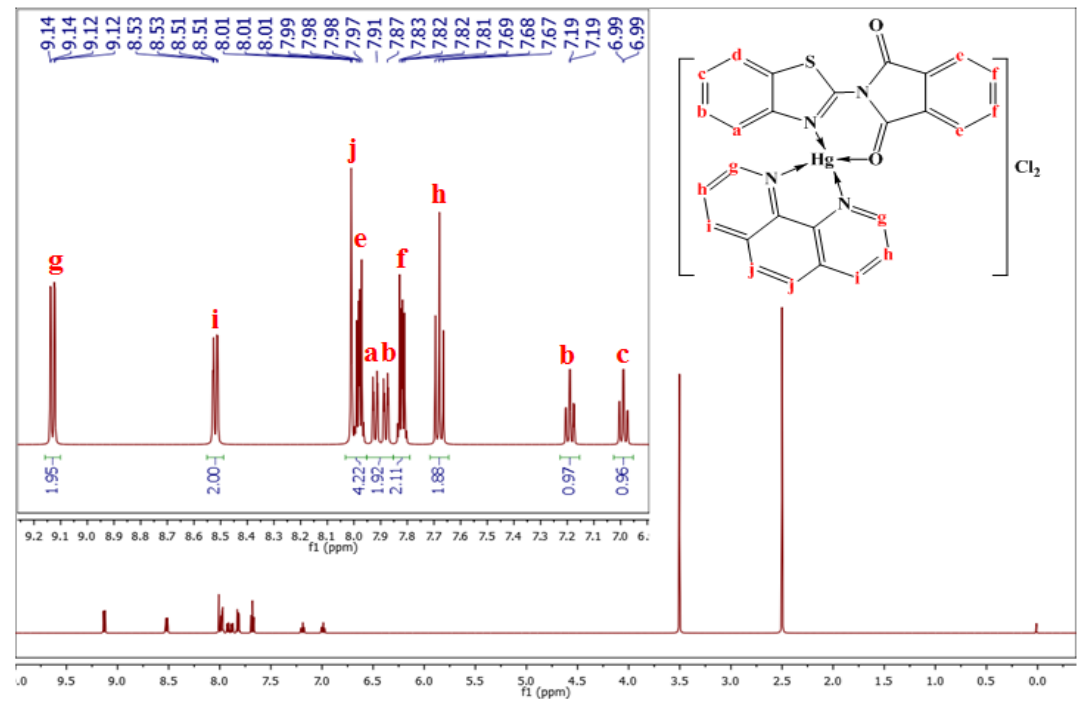

Fig 3. ${ }^{1} \mathrm{H}-\mathrm{NMR}$ Spectrum of $[\mathrm{Hg}(\mathrm{L})(\mathrm{Phen})] \mathrm{Cl}_{2}$ in DMSO-d ${ }^{6}$

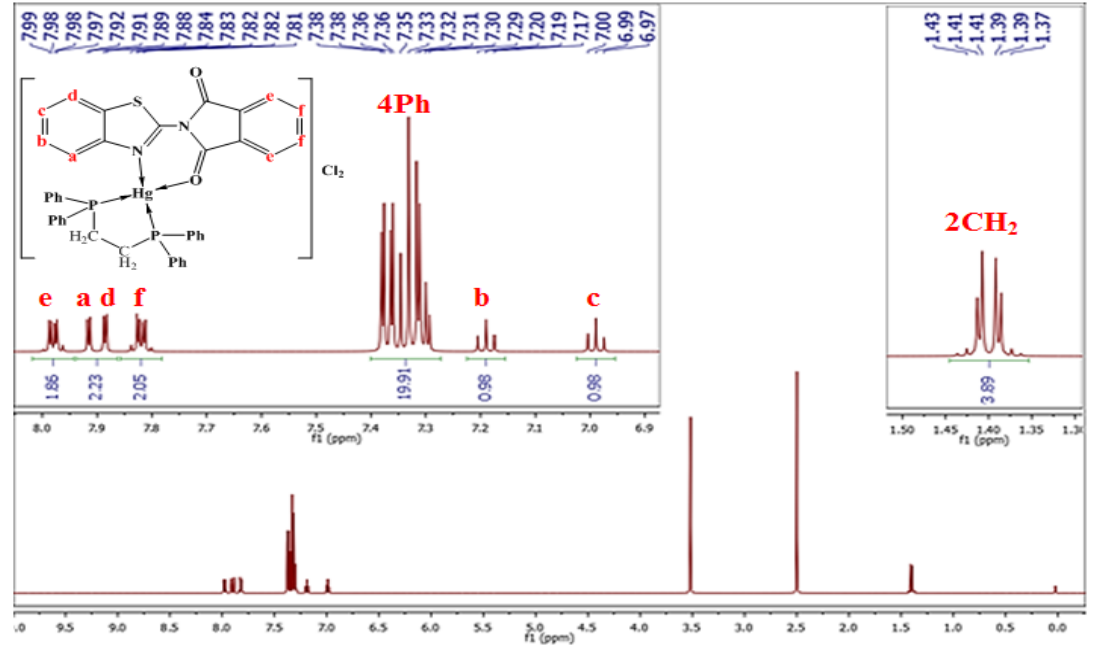

Fig 4. ${ }^{1} \mathrm{H}-\mathrm{NMR}$ Spectrum of $[\mathrm{Hg}(\mathrm{L})(\mathrm{dppe})] \mathrm{Cl}_{2}$ in $\mathrm{DMSO}^{-\mathrm{d}^{6}}$ 
Synthesis and Characterization of Phthalimide-benzothiazole

Mercury(II) Complexes with Diphosphine and Diamines

Ahmed Abdul sattar Irzoqi , Ahmed Shaker Marmmus Al-Janabi , Hayfa Muhammed Jirjes

\section{Conclusions}

1- Reaction of phthalic anhydride with 2-aminobenzothiazole took place through dehydration of the $\mathrm{H}_{2} \mathrm{O}$ in glacial acetic acid to given the phthalimide-benzothiazoles (L).

2- Reaction of phthalimide-benzothiazole ligand (L) with $\mathrm{HgCl} 2$ afford $[\mathrm{Hg}(\mathrm{L}) \mathrm{Cl} 2]$ complex which was non- conductive, (L) ligand behave as a bidentate chelate ligand bonds through $\mathrm{N} / \mathrm{O}$ to $\mathrm{Hg}(\mathrm{II})$ ion.

3- The $[\mathrm{Hg}(\mathrm{L})($ diamine $)] \mathrm{Cl} 2$ and $[\mathrm{Hg}(\mathrm{L})($ diphosphine $)] \mathrm{Cl} 2$ complexes have been prepared, the (L) ligand behave as a bidentate chelate ligand bonds through $\mathrm{N} / \mathrm{O}$ to $\mathrm{Hg}(\mathrm{II})$ ion, whereas the diphosphine and diamine ligands have been bonded as bidentate chelating ligands to give a tetrahedral geometry around the $\mathrm{Hg}(\mathrm{II})$ ion.

\section{References}

1. Silvia Regina Tozato Prado, Valdir Cechinel-Filho, Fatima Campos-Buzzi, Rogério Corre^a, Silvia Maria Correia Suter Cadena, and Maria Benigna Martinelli de Oliveira, Z. Naturforsch. 2004; 59c: 663-672.

2. S.M.Sami, R.T.Dorr, D.S.Alberts, A.M.Solyom and W.A.Remers, J. Med. Chem., 2000; 43: 3067-3073.

3. Wang J.-J., Liu T.-Y., Yin P.-H., Wu C.-W., Chern Y.-T., and Chi C.-W., Anticancer Research. 2000; 20: 3067- 3074.

4. F.Hassazadeh, M.Rabbani, G.A.Khodarahmi, A.Fasihi, G.H.Hakimelahi and M. Mohajeri, Res. in Pharm. Sci., 2007; 2(1): 35-41.

5. O. Fhid, T. H. Zeglam, S.haban E.A. Saad, T. Elmoug, A. Eswayah, M. Zitouni, W. Sdera, A. A. Edeep and A. Ebzabez, Der Pharma Chemica. 2014; 6(2): 234-238.

6. Md. Kudrat-E-Zahan, Md. Masuqul Haque, Lokonuzzaman Ahmmed, M. Sher Ali and Md. Saidul Islam, International Journal of Materials Science and Applications, 2015; 4(2): 120-123. 
Synthesis and Characterization of Phthalimide-benzothiazole

Mercury(II) Complexes with Diphosphine and Diamines

Ahmed Abdul sattar Irzoqi , Ahmed Shaker Marmmus Al-Janabi , Hayfa Muhammed Jirjes

7. M. R. Solanki \& M. C. Limbachiya, Asian Journal of Biochemical and Pharmaceutical Research, Issue 1 (Vol. 2) 2012, 317-322.

8. M. R. Solanki, G. D. Acharya and M. V. Hathi, E-Journal of Chemistry, 2009, 6(4), 1023 1028.

9. Aleksandra Sawczenko, Barbara Miroslaw, Tadeusz Lis and Anna E. Koziol, Pure and Applied Chemical Sciences, Vol. 2, 2014, no. 2, 73 - 86.

10. Wolfgang Beck, Z. Naturforsch. 2009, 64b, 1221 - 1245.

11. Kamalakanan P, Vengappayya D, Balasubramanian T, J. Chem. Soc., Dalton Trans., (2002)3381-3391.

12. Cechnil-Filho V, De Campos F, Corre R, Nunes R J, Yunes R A, A review: Qui'm. Nova. (2003), 26(2): 230-241.

13. M.Yosuva Suvaikin, A.Sabastiyan, C.Kalaivanan and C.Muthukumar, Chemical Science Review and Letters, 2013, 2(5), 310-318

14. Shunmugam Nagarajan, Syamantak Majumder, Upendra Sharma, Saranya Rajendran, Neeraj Kumar, Suvro Chatterjee, Bikram Singh, Bioorganic \& Medicinal Chemistry Letters, 23 (2013) 287-290.

15. S. F. A. Kettle, Coordination Compounds, Nelson, London, (1975).

16. W. Kuchen and H. Buchwald, Chem. Ber., 91(1958)2871.

17. K. A. Jensen and P. H. Nrelsen, Acta. Chem. Scand., 17(1963)1875.

18. G. W. Wrrschard and C. E. Griffin, Spectrochim. Acta. 19(1963)1905. 